\title{
Where did they go? Modelling transitions out of jobs ${ }^{\text {is }}$
}

\author{
Anders Frederiksen ${ }^{\mathrm{b}}$, Niels Westergaard-Nielsen ${ }^{\mathrm{a}, *}$ \\ a Aarhus School of Business, Center for Corporate Performance, Denmark IZA, Germany \\ ${ }^{\mathrm{b}}$ Hoover Institution, Stanford University, USA Aarhus School of Business, Center for Corporate Performance, \\ Denmark IZA, Germany
}

Received 20 September 2006; accepted 20 September 2006

Available online 28 November 2006

\begin{abstract}
We study individual job separations and their associated destination states for all individuals in the private sector in Denmark for the period 1980 to 2000, and account for their magnitude and cyclical flows. One finding is that individual and workplace characteristics as well as business cycle effects determine the individual behaviour. In policy simulations the consequences for individual labour market transitions are analysed. We find that structural and growth policies have different consequences for the economy due to the way they change workers' incentives. Policy interventions targeting displaced workers coming from plant closures are argued to be inefficient.
\end{abstract}

(C) 2006 Elsevier B.V. All rights reserved.

JEL classification: J63; J65; E24

Keywords: Business cycles; Job separations; Transition probabilities

\section{Introduction}

In recent years, several studies have described job and worker flows for various countries based on matched employer-employee data. See, for instance, Hamermesh et al. (1996) for the Netherlands, Abowd et al. (1996) for France, and Albæk and Sørensen (1998) for Denmark. These studies

\footnotetext{
is An earlier version of the paper has been presented at conferences and seminars in "Lavoro e Disoccupazione: Questioni di Misura e di Analisi," “Association Francaise de Science Economique," "the National Bureau of Economic Research”, IZA, CAED'01, and Panel'10. Comments from participants and, in particular, from John C. Haltiwanger and Bruno Contini are appreciated. We thank Anders Aagaard and Thomas Busch for valuable research assistance. The Danish Ministry of Employment and the Research Foundation of the University of Aarhus have financed the work.

* Corresponding author. Department of Economics, Aarhus School of Business, Center for Corporate Performance, Denmark. Tel.: +45 89486407.

E-mail address: nwn@asb.dk (N. Westergaard-Nielsen).
} 
document how individual establishments adjust their workforce in response to the multitude of shocks they are exposed to, and go on to develop the implications of this micro-level adjustment process for aggregate, macro-level quantities such as total job creation and total job destruction in an economy. The findings of this largely data-driven research have produced "stylized facts" about features of job and worker flows such as magnitude, persistence, cyclicality, and distribution across establishments.

The main finding in these studies is that large proportions of the labour force leave their jobs every year. Similarly, each year many jobs are filled with new employees. Implicitly, it is assumed that people leave their jobs due to external shocks to their firms. It is also assumed that most of these persons are looking for other jobs. The main flows cover, however, a number of different flows with different destinations, where it is less obvious that business cycle shocks are the determining factor. Some of the flows are probably determined by external factors such as retirement. There is, however, little knowledge about the nature of these flows.

In this paper, we account for the magnitude and the cyclicality of the flows taking place subsequent to a job separation from the private sector. The flows are broken up by destination states, where the main groups are unemployment, reemployment, and out-of-the-labour-force, as in Blanchard and Diamond (1990). Our contribution to the literature is a comprehensive decomposition of these flows. For the job-to-non-employment flows, as many as six different destination states are identified i.e. education, pension, unemployment, etc... Also, multiple destination states within the job-to-job flows can be identified. The immediate benefit of this detailed decomposition is an improved understanding of the flows and a "sharpening" of the analysis made on the data.

Furthermore, we study the importance of individual and firm characteristics as well as the influence of the business cycle on the probability of ending up in a particular destination state. This approach is motivated by the analysis in Anderson and Meyer (1994). ${ }^{1}$ We find large heterogeneity both within and between destination states, and explicitly discuss age and gender effects on the labour market flows. Also the business cycle is found to be an important determinant for the destination of flows.

In a policy section, we simulate the impact of a growth policy and a structural policy, which is changing the incentives of individuals by lowering the level of the unemployment benefits. The two policies are shown to have different implications for the economy due to the way they change workers' incentives. In this section, we also question the importance of policies targeting closing workplaces because the empirical findings indicate that individuals separating from closing workplaces do better in the labour market than individuals separating for other reasons. The main finding in this discussion is the importance of within-firm reallocations.

We make use of a special data set drawn from the register-based Integrated Database for Labour Market Research (IDA) created by Statistics Denmark. The data contain information on all employees of all establishments in all sectors. Our data runs from 1980 to 2000 and span two full business cycles. ${ }^{2}$

The next section briefly describes the data used; Section 3 contains results regarding the magnitude of different worker flows; Section 4 discusses the cyclicality patterns. The determinants for the individual job flows are estimated in Section 5, and Section 6 discusses policy implications. Section 7 summarises and concludes.

\footnotetext{
${ }^{1}$ Anderson and Meyer (1994) use United State unemployment registers in their analysis. Hence, they have information about the characteristics of the firm and an identifier for the individual. We extend this analysis by including information on human capital and the business cycle in addition to the characteristics of the firm.

${ }^{2}$ See Leth-Sørensen (1995) for further details about the IDA database. Data is described on http://www.asb.dk/ research/centresteams/centres/ccp/ccpresearch/databases/ida.aspx.
} 


\section{The data}

The IDA includes register-based information on all establishments and residents in Denmark. Persons and establishments are matched at the end of November each year, and we are able to obtain a comprehensive snapshot of all establishments in Denmark and all of their employees at this point of time each year from 1980 to 2000. Both establishments and persons are assigned a unique identification number and can be followed over time.

All flows calculated in this paper are based on comparing worker and establishment matches in consecutive Novembers. ${ }^{3}$ Hence, employment relationships (and associated flows) that last from, say, January to April of any given year are not picked up. As such, our figures should be considered a lower bound measure of actual flows. We focus on a worker's primary end-of-November employment relationship and ignore all other employment relationships of individuals who work multiple jobs at this time. ${ }^{4}$

The annual matching of the individual and the plant, due to the unique identification, makes it possible to associate individuals with both plant- and individual-specific characteristics on a large scale, providing a unique possibility of analysing the individual factors behind the flows and of answering the question of whether certain employees are more likely to move toward one destination than others.

The individual characteristics included in the analysis are the classical variables such as gender, age, and occupation, but also the policy variable replacement ratio. The replacement ratio is defined as the unemployment compensation to which an individual is eligible when unemployed relative to the income earned in the job, which she or he left. Unemployment Insurance compensation (UI-compensation) is calculated on an individual basis and depends upon the previous wage of the individual. At the lower end of the wage scale, compensation is, by law, calculated as 90 percent of the previous wage. From a certain point in the wage distribution UIcompensation is capped, with the result that the replacement ratio is 90 percent for low-wage earners and is decreasing with pay above this maximum wage rate. ${ }^{5}$

In this paper, we also make explicit use of the plant characteristics, i.e., sector and size. Furthermore, we include indicators for the plant's employment status. The indicators are constructed as a series of categories indicating if the plant is declining, expanding, or staying constant (less than $+/-10 \%$ change) in terms of employment together with an indicator for plant closing. These variables are interesting because the nature of the separation is believed to be an important signal when looking for a new job, see Gibbons and Katz (1991).

One factor blurring the true turnover is spurious job creation and destruction, resulting if firms change their formal identity in the registers from one year to the next. This is a problem present in all register based employer-employee data. Statistics Denmark has corrected changes in identity in the cases where it was obvious to Statistics Denmark that a real change had not happened. The main indicator used for the correction is the fraction of the workforce remaining employed. These corrections affect less than 5 percent of all firms.

\footnotetext{
3 The data provides no information on whether these flows are voluntary or non-voluntary.

${ }^{4}$ We consider for each worker the November establishment attachment from which he or she earned the most during a given year. The IDA registers up to three attachments for each worker in each year. However, most work checking the match validity has been carried out using primary November attachments. Hence, we ignore multiple job holding. Together, these omissions, on average, constitute 4.8 percent of all man-years of employment.

5 See Andersen et al. (2001) for how UI-benefits are calculated.
} 


\section{Magnitude of flows}

In this section, we analyse the magnitude of flows and their distribution over destination states. The concepts and definitions used are in accordance with the conventional definitions suggested by Davis et al. (1996). A separation in time $t\left(\mathrm{sep}_{\mathrm{t}}\right)$ is defined as a situation where the person is employed at a plant in time t but not employed at the same plant in time $t+1$, and a stayer $\left(s_{t}\right)$ is a person who is employed at the same plant in both periods. Similarly, a hire in time $t\left(h_{t}\right)$ is defined as a situation, where the person is at the workplace in $t$ but not in $t-1$. When calculating the proportion of separations, the denominator is chosen to be the average employment in year $t$. This is calculated as the number of stayers, plus the average of separations and hires.

$$
\operatorname{Sep}_{t}=\frac{\operatorname{sep}_{t}}{1 / 2 *\left(\operatorname{sep}_{t}+h_{t}\right)+s_{t}}
$$

In Table 1, we have summarised annual transitions over all 20 years. The basic facts are: 29 percent of all employments in a given year in the private sector end in a separation. Out of the total level of separations, two thirds move to a new job (according to the industry classification NACE9 or ISIC codes), thus one third of all separated is found without a job the following year. Among the latter group, a little more than half (16 percent of all separations) are found among the unemployed in the subsequent year. One eighth (4 percent of all separations) are found to be out of the labour force, receiving no unemployment benefit. They may receive sickness benefits, or they may have withdrawn without any specific transfer income. One tenth (3 percent of all separations) have started an education, and only a minor portion corresponding to one tenth of the non-employed is found to have left employment because of retirement.

Table 1

Decomposition of separations on destination states in the private sector, 1980 to 2000

\begin{tabular}{|c|c|c|}
\hline & \multicolumn{2}{|l|}{ Separations } \\
\hline & $\%$ of all employment & $\%$ of all separations \\
\hline Total & 29.53 & 100.00 \\
\hline Job-to-job & 20.86 & 70.67 \\
\hline \multicolumn{3}{|l|}{ Of which } \\
\hline New plant in the same firm & 2.80 & 9.48 \\
\hline New firm in the private sector & 13.51 & 45.75 \\
\hline Public sector & 2.36 & 8.00 \\
\hline No physical workplace & 1.15 & 3.90 \\
\hline Self-employment & 1.04 & 3.54 \\
\hline Job-to-no-job & 8.66 & 29.33 \\
\hline \multicolumn{3}{|l|}{ Of which } \\
\hline Unemployment & 4.80 & 16.24 \\
\hline Education & 0.95 & 3.22 \\
\hline Post employment wage & 0.65 & 2.21 \\
\hline Pension & 0.34 & 1.16 \\
\hline Out of the labour force & 1.60 & 3.90 \\
\hline New Labour Market Program & 0.32 & 1.08 \\
\hline
\end{tabular}

Note: The new labour market program (NLP) was introduced in 1994, and accounts for 4.98 percent of the separations in 1994, and 3.95 percent in 1995; in later years that number is reduced. The NLP separations enter the decomposition in the same way as do the other variables, but they are highly underrepresented since they occur in the later years. 
Table 2

Correlations with the dGDP and standard errors

\begin{tabular}{llc}
\hline Correlations & Contemporaneous & Standard Errors \\
\hline Total separations & -0.331 & 0.014 \\
New plant in the same firm & -0.162 & 0.005 \\
New firm in the private sector & -0.088 & 0.017 \\
Public sector & -0.171 & 0.002 \\
No physical workplace & 0.077 & 0.004 \\
Self-employment & -0.180 & 0.001 \\
Unemployment & -0.181 & 0.014 \\
Education & -0.538 & 0.002 \\
Post employment wage & 0.354 & 0.001 \\
Pension & -0.239 & 0.001 \\
Out of the labour force & -0.293 & 0.001 \\
\hline
\end{tabular}

Note: Correlation between the New Labour Market Programs and the dGDP has not been calculated due to its late introduction.

\subsection{Discussion}

Of the job-to-job changes that constitute 71 percent of all job separations, 46 percent-points (around two thirds) are due to transitions to other firms in the private sector. While this is hardly surprising, it may be more surprising that 9.5 percent of all transitions are relocations from one plant to another within the same firm. Sector changes are made by only 8 percent of all those leaving a private sector job. There is a small flow into the category "no physical workplace," which covers those who do not have a daily working place other than their home (i.e., salespersons working from home or consultants who are not self-employed). The flow into selfemployment constitutes 4 percent-points of all separations.

Half of the 30 percent who move to non-employment become unemployed. These are most likely to receive unemployment benefit in the Danish context. 4 percent of all separating or one

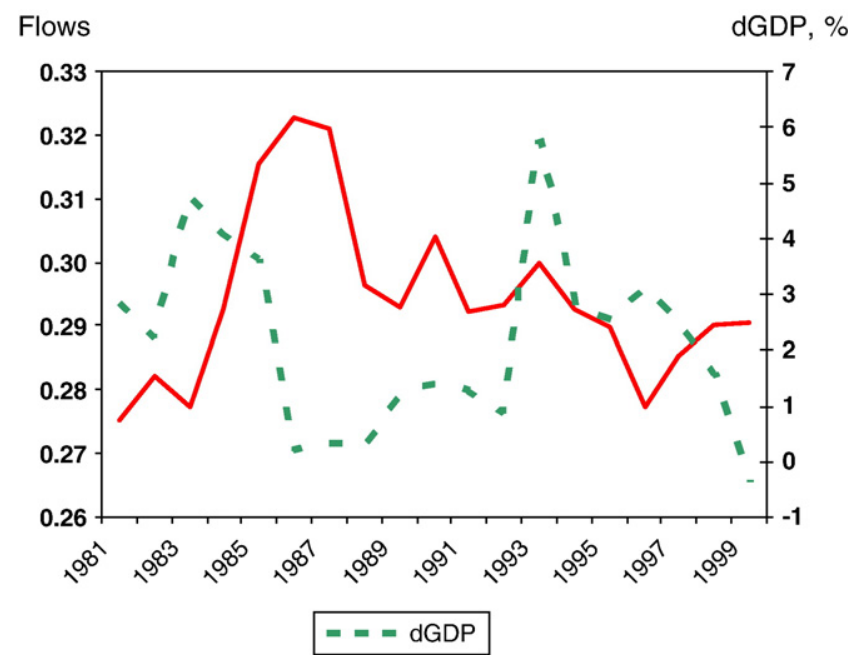

Fig. 1. Separations and changes in the GDP. 
fifth of the job-to-non-employment leavers, are categorised as out-of-the-labour-force, which is basically defined as the residual group. Those are most likely receiving sickness benefit or are on maternity leave. A relatively small group -3 percent of all separators - go to education, while 2 percent turn themselves into the early retirement program available for 60 years plus. This is called post employment wage. Many choose this early retirement plan, and therefore fewer are categorised as on pension. Together these "natural causes" for separations account for only 3 percent of all separations among the 18 to 66 year olds. This measure does, however, not account for the flow from unemployment and out-of-the-labour-force into retirement and the post employment wage.

The new labour market program, NLP, has its own category. NLP was introduced in 1994. In the beginning, NLP mainly covered several leave schemes. The special feature of NLP compared to earlier programs was that both employed and unemployed were eligible. The idea of the program was to create incentives for people to leave the labour market temporarily and thus create possibilities for the unemployed to gain a foothold. One of the most popular leave programs was an extended maternity leave. Another was a leave scheme to take education almost according to your own choice. These programs became very popular, so popular, in fact, that almost 1.5 percent of the entire labour force made use of them in each of the first few years. To a certain degree, participation in these programs was an alternative to both work and unemployment as the unemployed could participate in the leave schemes as well (see Westergaard-Nielsen, 2001).

\section{The cyclicality of flows}

So far, we have been looking at the magnitude of flows. In this part, we will look at the cyclicality. First, Table 2 shows that separations are negatively correlated with changes in the GDP (dGDP) and the coefficient of correlation for the whole period is -0.33 . The level of these separations in a single year is between 27 percent and almost 33 percent. (See Fig. 1).

Table 2 emphasises the importance of distinguishing between destination states because the flows have different correlations with the GDP. This situation is illustrated by the transitions from the private sector to a new job in the private sector, where the coefficient of correlation is -0.09 and transitions from the private sector to the public sector, where the correlation is -0.17 . The latter shows that the public sector is pulling people in low growth periods in accordance with a Keynesian demand policy. This observation is also an indication for the attractiveness of working in the private sector once you have been employed in that sector. ${ }^{6}$ Equally pronounced is the negative correlation found between reallocations within the same firm and the GDP. This finding shows that reallocation of workers within the same firm is more likely in periods of low growth. This observation is highly related to the reallocation, firm, and plant closure discussion we make in Section 6.

The category "no physical workplace" is weakly pro-cyclical, showing that the number of people who take up this semi-self-employment is increasing in good times. This intuitive result does not carry over to the transitions into self-employment, which is showing a negative correlation with changes in the GDP. A possible explanation for this correlation is that selfemployment is considered as an alternative to unemployment. In technical terms, the present value of self-employment is below what can be achieved in a job in the private sector, but above the present value of becoming unemployed. Adding to this explanation is the existence of a

\footnotetext{
${ }^{6}$ This finding is supported by the fact that, once employed in the private sector, it is six times as likely that you stay in the private sector compared with moving into the public sector (see Table 1).
} 


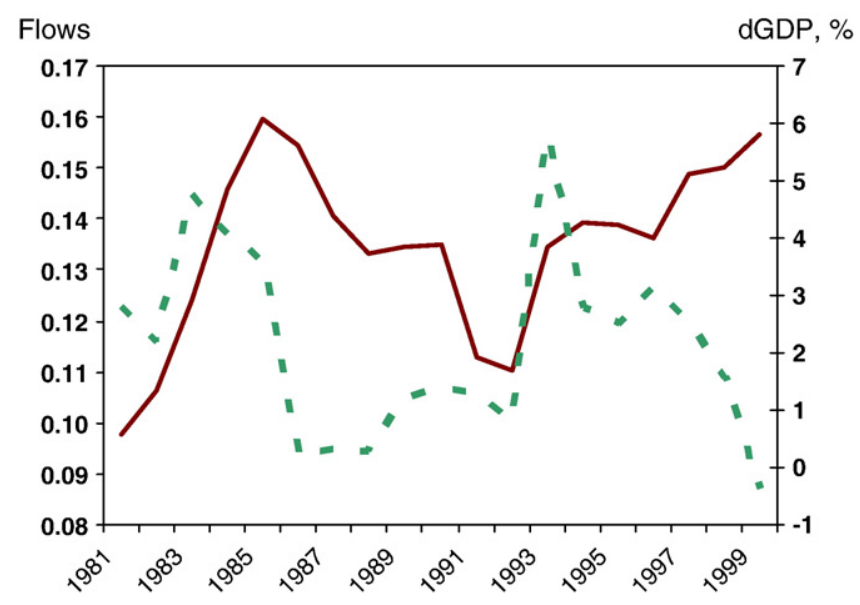

Fig. 2. Separations to different firms on the private sector.

program that, for the whole period, subsidized, the unemployed who started their own business. The required unemployment spell was three months, and the subsidy consisted of 50 percent UIbenefits for a three-year-period.

Figs. 2-5 illustrate some of the correlation coefficients from Table 2. Fig. 2 shows that a larger part of the individuals separating leave for jobs in different firms in the private sector at the end of an upswing. Fig. 3 shows that the reallocation between plants in the same firm increases when the business cycle goes down, as was clearly the case in 1986 to 1987.

For the job-to-unemployment separations, the counter cyclicality is highly pronounced (Fig. 4). Here the correlation is -0.18 . The years with low economic growth from 1987 to 1993 result in an increasing flow to unemployment. Only the strong growth in 1994 seems to be able to break the upward trend in the flow into unemployment. It is also plausible that the introduction of the NLP in

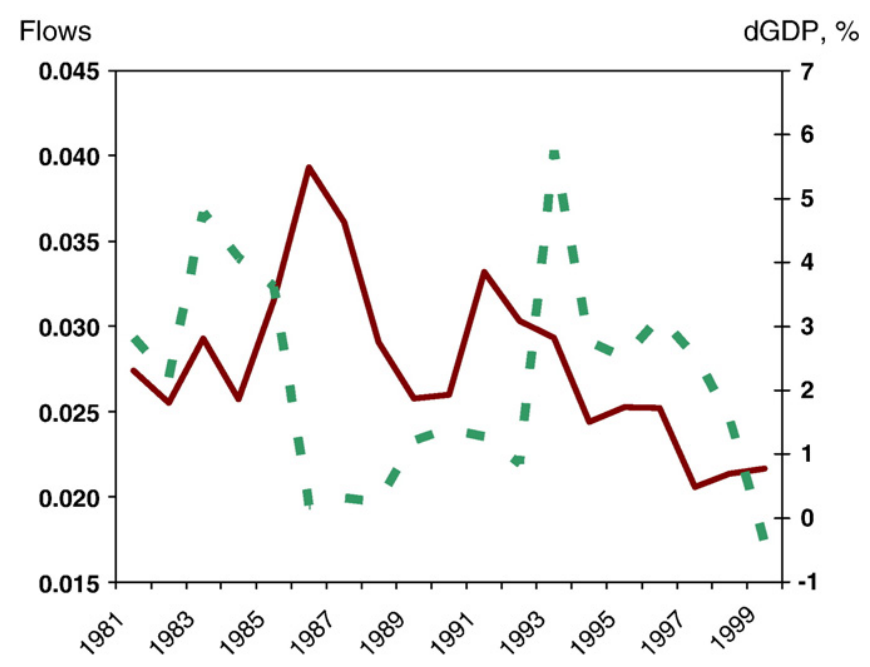

Fig. 3. Separations (rellocation) to another job within the same firm. 


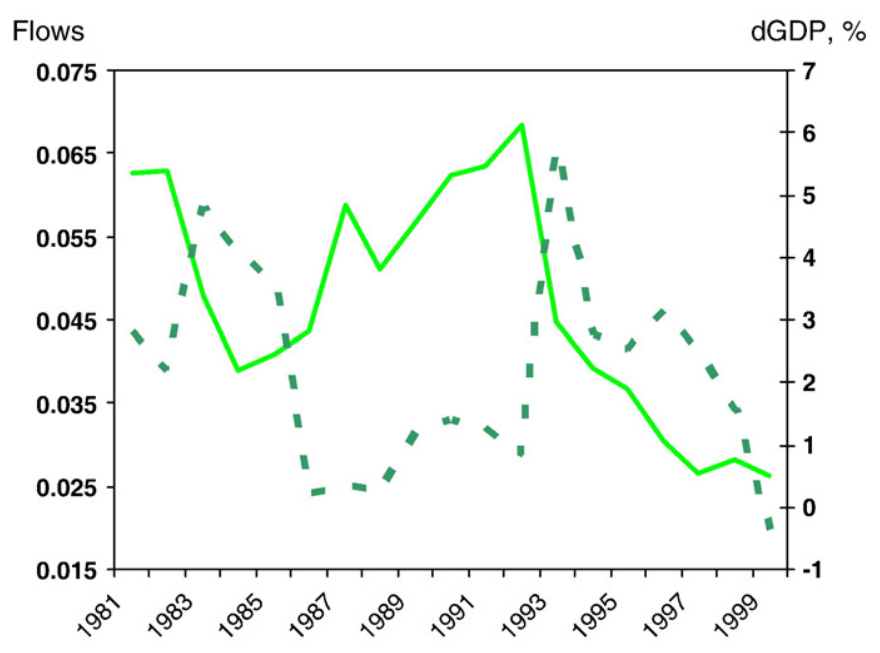

Fig. 4. Separations into unemployment.

1994 helped reduce the flow into unemployment. The development in 1995 suggests that the NLP plays a role in redirecting the unemployed, since the two curves are positively correlated for the first time. In fact, a closer inspection shows that the NLP "absorbed" 1.5 percent of the labour force, or 5 percent of all separations in 1994, and a little less in 1995. However, adding these numbers to the flow into unemployment does not, by any means, explain the reduction in unemployment in 1994 and 1995, but makes it less abrupt. Westergaard-Nielsen (2001) discusses the effects of the NLP, and finds that it is not the main explanation for the subsequent reduction of unemployment.

The relatively small number of people leaving employment to start an education is found to be clearly counter cyclical (the correlation coefficient is -0.54 ). The most likely explanation of the

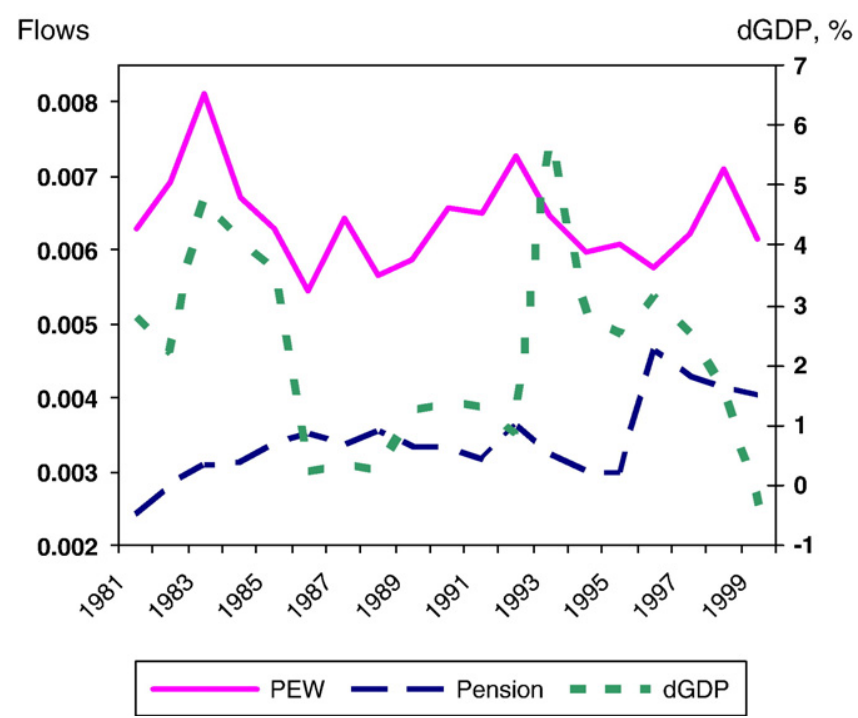

Fig. 5. Separations into the PEW and pension. 
Table 3

Transition probabilities for different age and gender groups

\begin{tabular}{|c|c|c|c|c|c|c|c|c|c|c|}
\hline & $\begin{array}{l}\text { New employment } \\
\text { in private sector }\end{array}$ & $\begin{array}{l}\text { Stay with } \\
\text { the same firm }\end{array}$ & $\begin{array}{l}\text { Public } \\
\text { sector }\end{array}$ & $\begin{array}{l}\text { No physical } \\
\text { workplace }\end{array}$ & $\begin{array}{l}\text { Self- } \\
\text { employment }\end{array}$ & Unemployment & Education & PEW & Pension & $\begin{array}{l}\text { Out of the } \\
\text { labour force }\end{array}$ \\
\hline Woman, Junior & .42 & .03 & .10 & .03 & .01 & .27 & .06 & 0 & 0 & .06 \\
\hline Woman, Middle-aged & .37 & .04 & .08 & .03 & .03 & .32 & .01 & 0 & .03 & .09 \\
\hline Woman, Senior & .15 & .02 & .03 & .02 & .01 & .30 & 0 & .25 & .10 & .10 \\
\hline Man, Junior & .53 & .03 & .07 & .04 & .02 & .21 & .06 & 0 & 0 & .04 \\
\hline Man, Middle-aged & .47 & .04 & .06 & .04 & .05 & .25 & .01 & 0 & .03 & .06 \\
\hline Man, Senior & .19 & .03 & .02 & .02 & .02 & .23 & 0 & .33 & .10 & .06 \\
\hline
\end{tabular}

Note: Characteristics for the group of interest are: Employment in manufacturing, white-collar, medium-sized firm, no employment change in workplace, high replacement ratio, and no change in the GDP. 
counter cyclicality is that the foregone earnings in a human capital function increase in periods with economic growth and decrease in slumps and that makes people deselect and select education accordingly. It is, at the same time, less likely that training and education schemes under various labour market policies are responsible for the counter cyclicality in the flow between employment and education, because the general rule until the NLP was introduced in 1994 was that a person should have been unemployed for 21 out of the last 24 months before he could be placed on a program.

The flow into out-of-labour-force is found to be clearly counter cyclical, with a correlation coefficient of -0.29 . The negative correlation indicates that the economic situation is important to the decision of whether or not to leave the workforce. A possible explanation is that if a person suffers from quick depreciation of human capital when separating, the knowledge about the business cycle may enforce the decision permanently to leave the workforce. Furthermore, individuals who plan to leave the workforce on a temporary basis may plan to do so in slumps because the opportunity costs are lower in this period.

Transition into old-age retirement and disability-conditioned retirement (together called pension) in Fig. 5 appears to be vastly a-cyclical. The pension curve seems to be influenced by a reform in 1984 that allowed more people to get an early pension. The flow into post employment wage (also Fig. 5) shows two spikes around growth peaks, with the result that PEW, which is really early pension, is positively correlated with growth. Both flows are somewhat influenced by new programmes in 1992, 1993, and 1994 that allowed unemployed members of the UI system who were between 50 and 60 years old to leave the labour market with a benefit slightly below the UI-benefit. These are counted together with PEW, and are responsible for the latest peak.

\section{Individual flows and their determinants}

We will now direct the analysis toward the individual level, investigating the determinants for the flows we have looked at in the first part of the paper and combining these with the influence from the macro environment. The intention is to answer the question if a particular group of people is relatively more likely to end up in a particular destination state after a job separation. The results from this analysis provide important insights into the labour market. As an example, it identifies the individuals marginalized in the labour market (i.e., individuals moving from employment to unemployment or out of the labour force). Also, looking at the job-to-job transitions provides clear indications for the skills demanded in the market because labour demand is a necessary condition for this type of transition.

Search theory provides a convenient framework for thinking about and modelling worker flows (see Mortensen and Pissarides (1999a,b) for a recent survey). In these models, individuals compare the present value of different labour market states and choose the state providing the highest utility. In general, the valuation of the states depends, on the individual and plant characteristics as well as the state of the labour market. The multinomial logit is capable of capturing these ideas, which is the reason this model is applied in the subsequent analysis.

The dependent variable used in the econometric analysis is the destination state of the employee. This choice is explained by characteristics of the plant and the conditions in the plant at the time of the job separation (closure, downsizing etc.), a comprehensive set of individual characteristics (age, gender etc.) together with a set of policy variables (replacement ratio and GDP). For identification purposes the most frequently used destination state, "stay in private sector", is chosen as the reference category. 
The results from the multinomial logit model are shown in the Appendix. ${ }^{7}$ The point estimates are difficult to interpret due to the normalization required for identification. For this reason, predictions are used to present the empirical results. By specifying the characteristics of the group of interest, and using the estimated parameters from the multinomial logit, the probability of transiting to a given state for the specified group is obtained.

\subsection{The age and gender effect}

In a first set of predictions, we evaluate the effects of gender and age on the distribution of flows across destination states. The intention is to illustrate the difference in mobility patterns of the different age and gender groups. The group considered is low-paid, white-collar, and working in a medium-sized manufacturing workplace, with constant employment and an environment experiencing no macroeconomic growth. The transition probabilities are presented in Table 3 for different gender-age combinations. Three age groups are chosen: junior, 18 to 30 years; middleaged, 30 to 50 years, and seniors; 50 and above.

There is a clear tendency for both men and women that senior workers, given a separation from a workplace are much less likely to become reemployed as compared with younger workers. The transitions into unemployment (around 25 percent of all separations) are also at a relatively low level for senior workers. In fact, it is lower for the senior workers than for the group of middleaged workers, indicating that the transitions from employment for the senior workers will mainly have destination states out of the labour market. Because the pure out-of-the-labour-force state is fairly constant over age groups, the important destination states for senior workers are post employment wage and pensions. These states are found to account for as much as 35 percent of all separations among senior female workers, and 43 percent of all male workers.

The picture for the youngest cohorts is different in many respects. First of all, the reemployment transitions (new employment + stay with same firm + public sector + no physical workplace) are large, and account for more than 60 percent of all separations for men and a little less for women. The high reemployment probability is probably due to on-the-job search, where young workers are searching for new jobs that are dominating the initial match. ${ }^{8}$ Education is the destination state that in particular makes the youngest workers different from the other age groups. Education accounts for around 6 percent of all transitions for young men and women. The high reemployment probability and the extensive use of education explain why the youngest age group has the lowest probability of ending up in unemployment.

The middle-aged workers have almost the same probability of transferring to a nonemployment state as young workers, although the probability of becoming unemployed is higher. This result is in part driven by the fact that middle-aged individuals have completed their formal education but also by their higher likelihood of being eligible for unemployment benefits.

There are three observations that strike the eye when looking for gender differences. Firstly, the reemployment probability is almost 10 percent lower for women relative to men. Secondly, women have a higher probability of ending up in the out-of-labour-force state, which, for the younger women, is explained mainly by maternity leave and extended childcare leave, but is unexplained for the other age groups. Finally, sector changes are more pronounced for women.

\footnotetext{
${ }^{7}$ Due to the burdensome computations, the data used in the estimation are limited to a random sample of 10 percent of the individual employment histories registered in the IDA database. The number of observations in the regression is still above 800,000 , so it is believed that this reduction does not induce any loss of generality.

${ }^{8}$ This observation is established in the literature by Topel and Ward (1992).
} 
Table 4

Elasticities for changes in transition probabilities, calculated from policy simulations

\begin{tabular}{lcc}
\hline & $\begin{array}{c}\text { GDP increased by } \\
\text { one percentage point }\end{array}$ & $\begin{array}{r}\text { Unemployment benefits } \\
\text { reduced by one percent }\end{array}$ \\
\hline Same firm & -1.140 & 0.330 \\
Another firm in the private sector & 4.168 & 0.167 \\
Public sector & 0.185 & -0.452 \\
No physical workplace (work from home) & 0.360 & -0.398 \\
Self-employed & -0.388 & 0.142 \\
Unemployment & -10.728 & -0.100 \\
Education & -3.405 & -0.762 \\
Post employment wage & -0.692 & -0.174 \\
Pension & 2.126 & -0.716 \\
Out of labour force & -3.309 & -0.271 \\
\hline
\end{tabular}

This finding may be explained by a relatively higher public-sector demand for female workers, or a relatively higher risk-aversion of women. The authors point to these potential explanations without making any conclusions.

\section{Policy implications}

In the estimated multinomial logit regression, two policy instruments were included (i.e., the replacement ratio and the GDP). These instruments can be used to simulate the partial effects of a hypothetical reform that chances the workers incentives through lower UI benefits and a reform that stimulates the overall growth rate of the economy. It is important to notice the different nature of the two hypothetical policy interventions or shocks. The growth policy, or shock, is modelled as a one-period increase in growth, and, hence, the resulting change in flows is only of a temporary nature. The structural policy, on the other hand, can be thought of as a permanent change. However, the long-run effects of the two policies have to be analysed within the framework of a general equilibrium model in order to take account of feedback mechanisms. The two policy interventions are of course of completely different magnitudes because a $1 \%$ change in GDP is much larger in terms of economic effects than a $1 \%$ reduction in benefits. The elasticities for the policy changes can be seen in Table 4 .

First, we simulate the impact of an exogenous shock, which increases the growth rate in the economy in a single year for example, expansive fiscal policy. The improved economic condition has very desirable consequences for the economy because it reduces unemployment and increases flows into new jobs.

The growth in the GDP has some undesirable consequences as well because the better labour market conditions resulting from economic growth reduce the flows into education and selfemployment. Similarly, the flow into post employment wage is reduced by 0.7 percent. These observations are naturally explained by opportunity cost arguments, where the temporary higher present value of staying in the labour market makes non-labour-market states less attractive. The exception to this is the positive coefficient to pension, which also includes early retirement due to health related reasons. It is well-known that workers with bad health hide among the unemployed when unemployment is high. When unemployment is reduced, the pressure on the unemployed makes this group apply for pension. Finally, the increased growth also results in increased job flows into the public sector and into "work from home." 
Table 5

Transition probabilities, given different separation conditions

\begin{tabular}{|c|c|c|c|c|c|c|c|c|c|c|}
\hline & $\begin{array}{l}\text { New employment } \\
\text { in private sector }\end{array}$ & $\begin{array}{l}\text { Stay with } \\
\text { the same firm }\end{array}$ & $\begin{array}{l}\text { Public } \\
\text { sector }\end{array}$ & $\begin{array}{l}\text { No physical } \\
\text { workplace }\end{array}$ & $\begin{array}{l}\text { Self- } \\
\text { employment }\end{array}$ & Unemployment & Education & PEW & Pension & $\begin{array}{l}\text { Out of the } \\
\text { labour force }\end{array}$ \\
\hline $\begin{array}{l}\text { Woman, Closing } \\
\text { workplace }\end{array}$ & .47 & .10 & .06 & .09 & .02 & .18 & .01 & 0 & .01 & .07 \\
\hline $\begin{array}{l}\text { Woman, Reducing } \\
\text { workplace }\end{array}$ & .41 & .07 & .07 & .04 & .02 & .28 & .01 & 0 & .02 & .07 \\
\hline $\begin{array}{l}\text { Woman, No change } \\
\text { in employment }\end{array}$ & .37 & .04 & .08 & .03 & .03 & .32 & .01 & 0 & .03 & .09 \\
\hline $\begin{array}{l}\text { Woman, } \\
\text { Expanding workplace }\end{array}$ & .36 & .04 & .07 & .03 & .03 & .33 & .01 & 0 & .02 & .09 \\
\hline Man, Closing workplace & .53 & .11 & .03 & .11 & .03 & .13 & 0 & 0 & .02 & .04 \\
\hline $\begin{array}{l}\text { Man, Reducing } \\
\text { workplace }\end{array}$ & .50 & .08 & .05 & .05 & .04 & .21 & .01 & 0 & .02 & .04 \\
\hline $\begin{array}{l}\text { Man, No change in } \\
\text { employment }\end{array}$ & .47 & .04 & .06 & .04 & .05 & .25 & .01 & 0 & .03 & .06 \\
\hline $\begin{array}{l}\text { Man, Expanding } \\
\text { workplace }\end{array}$ & .46 & .05 & .05 & .04 & .05 & .26 & .01 & 0 & .02 & .06 \\
\hline
\end{tabular}

Note: Characteristics for the group of interest are: Employment in manufacturing, white-collar, medium-sized firm, no employment change in workplace, high replacement ratio, and no change in the GDP. 
In a second simulation, we investigate a structural policy, which directly changes the economic incentives of the agents by lowering the maximum level of unemployment benefits by 1 percent. A reduction of the benefits is intended to motivate the workers not to choose the unemployment state, but as correctly pointed out by Atkinson and Micklewright (1991), a reduction in the "value" of the unemployment state potentially increases the transitions into other undesirable nonemployment states.

The consequence of a reduction in the maximum of unemployment benefits is that the replacement ratio is reduced. This makes it clearly less attractive to receive unemployment benefit, and, as a consequence, we see that people tend to stay in the current firm, and, if they separate, the tendency to find another private sector job is increased. The elasticity with respect to self-employment is also positive. As expected, the elasticity with respect to unemployment is negative. It is more surprising that the elasticity, with respect to employment in the public sector, education, pension, and the PEW, are all negative. The main reason is probably that a number of people with high replacement coefficients (low wages) used to get subsidized jobs in the public sector and received subsidized education. These states become less attractive after the reduction of benefits since the "wage" in the low-end subsidized jobs is equal to the UI-benefits. It is interesting that the effect of reducing the UI-benefit maximum is highest on transitions between jobs, and not on transitions to unemployment. This illustrates empirically that UI-benefits are closely related to the amount of temporary layoffs in Denmark, and that UI-benefits serve as insurance for job movers, as mentioned in the introduction.

Although the expansion policy has the largest elasticities, it is worthwhile to note that usually this cannot be maintained over a longer period due to budget constraints. In contrast, the structural change in the benefits can be, in effect, forever.

In a third simulation, we use information about the employment situation of the workplace from which the person is separating because these conditions may be an important signal for the worker quality when searching for future employment (see Gibbons and Katz, 1991). We have categorised the workplace via the following four groups: workplaces expanding more than 10 percent, less than $+/-10$ percent, reducing more than 10 percent, or closing. Holding the characteristics of the reference person fixed and varying the indicators for the employment situation the effect of the signals on the employees' destination state can be established. Empirically these signals appear to be important, see Table 5.

Rescuing closing firms has had a high priority in some countries. Most often the reason has been fear that workers laid off from closing companies would have difficulty finding new employment. This policy had widespread support in Europe in the 1980s. Later, it had been abandoned, mostly because of the introduction of the single market in the European Union. However, some countries have practised huge placement and early retirement programs when big firms closed. Storrie (1993) describes how this policy has been followed in Sweden. One of the results he has found is that people caught in one of the big plant closures on the Swedish West Coast actually did much better than predicted. Since Denmark has never been very active in giving immediate assistance to displaced workers, it is very interesting to see that somebody separating from a closing workplace is actually less likely to become unemployed than a person separating from an expanding or contracting firm (see Table 5).

Our predictions evaluated for middle-aged men and women show that the probability of ending up in unemployment is two thirds for a person being dismissed from a closing workplace, compared with persons separating under other circumstances (.18 against .32 for women, and .13 
against .25 for men). This is noteworthy because we know that those involved in a plant closure are all laid off, while an unknown fraction of those separating from other workplaces are actually quitting. The explanation is closely related to signalling (Spence, 1973). The reason is that plant closures dismiss high-ability workers together with low-ability workers, while single layoffs are believed to affect mostly low-ability workers. The phenomenon is also described as lemons and non-lemons by Gibbons and Katz (1991). Furthermore, people who are involved in a plant closure will have an interest in signalling the circumstances because they can use it as an advantage, compared with the average worker not dismissed in a plant closure. Other workers do not have the same interest. Finally, another argument is that workers in plant closures might get a warning earlier than workers involved in single layoffs, and this may give them an advantage in their job search. Labour protection laws prescribe early notice in the case of mass dismissals, where single dismissals require no notice or only short notice in Denmark, see Andersen et al. (2001). However, it is interesting that for both men and women there is a clear ranking in the unemployment probabilities, depending upon the cause of separation, where those separating from an expanding workplace are most prone to become unemployed.

The other set of findings concerns the probability of being reemployed in a new or in another plant owned by the same firm. For men leaving expanding and steady workplaces, the re-employment probability is 51 percent. For men leaving closing plants, it is 64 percent and for reducing workplaces, it is somewhat lower. These numbers are lower for women, but there is the same difference between plant statuses. However, our results with respect to the probability of getting new employment in the private sector (column 1) show that the main reason for these differences is that employees from closing and contracting plants are more likely to get transferred to other parts of the same firm. Correcting for within-firm transfers, people involved in plant closures are found to be only marginally better at getting new employment compared with other groups of people separating ( 7 percentage points for men, and 11 percentage points for women). Thus, the seemingly better employment prospects for people involved in plant closures are, to some extent, due to a higher probability of being transferred to other parts of the firm. However, unemployment is still lower for the group involved in plant closures because they are less likely to drift to other statuses. So even after having controlled for the group who gets reallocated, there is still room for the lemon explanation of Gibbons and Katz (1991).

But it is remarkable that most of the difference between persons depending upon the cause for the separation is actually due to reallocation within the same firm. This indicates that the information on quality and performance is mostly conveyable within the firms and is more difficult to transfer to third parties.

Another result is that those from plant closures are not more likely to become employed in the public sector, as would be the case if the public sector actively provided jobs for employees from closed firms. This clearly fits with the traditional policy in Denmark, where the state has never been active in the reallocation of employees, unlike Sweden which has.

\section{Conclusion}

This paper has analysed individual job separations and flows from the private sector at a highly differentiated level. The results are believed to be valid for other liberal labour markets, although each has its own distinct features. The main differences between the Danish and other liberal labour markets are the high replacement ratios in Denmark and the existence of a close social network. Our results demonstrate that under these circumstances turnover is high for all age 
groups, unlike heavily regulated labour markets, where turnover tends to be concentrated in the younger age groups.

In the first part of the paper, we study individual job separations and flows from the private sector using the IDA database. We identify 11 different destination states, and show the full distribution of labour market flows and their cyclical behaviour. The findings in this section confirm that the level of job separations taking place each year is high, and emphasise that there is a substantial risk of becoming unemployed given a job separation.

To learn more about the nature of the separations, a multinomial logit model is estimated. Individual characteristics such as age, gender, occupation, and replacement ratio are included in the analysis, together with the workplace characteristics of size, sector, and employment conditions. Also, the business cycle effects are taken into account. We find that variables of all three classes are important in explaining the individual behaviour, and that there is large heterogeneity both within and between destination states.

In a policy section, we compare the effects of a hypothetical change in the UI benefits with a push to the overall growth of the economy. We show that growth and structural policies have different consequences for the economy due to the way they change workers incentives. The most remarkable result is that reducing the maximum benefit actually increases the probability that someone stays in the same firm by more than it reduces unemployment. This indicates clearly that the UI-benefit serves as a safety net for job movers. A third simulation deals with signalling. It is found that employees involved in plant closures are generally more likely to get a new job than are employees who have been laid off under other circumstances. Similar findings are usually explained by a lemon argument. However, when we control for those workers who are reallocated to a different plant within the same firm, the finding is much less pronounced, indicating that favourable signals on experience and performance are best conveyed within the firm. This provides a clear signal to policymakers of not being over-concerned about reemployment of those workers involved in plant closures. They should probably be more concerned about overall growth conditions.

\section{Appendix A}

Multinomial logit for flows out of private sector employment

\begin{tabular}{|c|c|c|c|c|c|}
\hline & $\begin{array}{l}\text { Stay with the } \\
\text { same firm }\end{array}$ & Public sector & $\begin{array}{l}\text { No physical } \\
\text { workplace }\end{array}$ & $\begin{array}{l}\text { Self- } \\
\text { employment }\end{array}$ & Unemployment \\
\hline Woman $(=1)$ & $0.043(0.010)$ & $0.599(0.010)$ & $-0.042(0.014)$ & $-0.367(0.016)$ & $0.475(0.008)$ \\
\hline Ages $18-30$ & - & - & - & - & - \\
\hline Ages $31-50$ & $0.362(0.010)$ & $-0.076(0.010)$ & $0.094(0.014)$ & $1.100(0.015)$ & $0.307(0.008)$ \\
\hline Ages $>51$ & $0.798(0.014)$ & $-0.088(0.019)$ & $0.539(0.021)$ & $1.345(0.022)$ & $1.147(0.011)$ \\
\hline $\begin{array}{l}\text { Replacement ratio } \\
\quad 70-90 \%\end{array}$ & - & - & - & - & - \\
\hline Replacement ratio $50-70 \%$ & $0.304(0.012)$ & $-0.358(0.011)$ & $-0.339(0.016)$ & $-0.197(0.018)$ & $0.113(0.009)$ \\
\hline Replacement ratio $<50 \%$ & $0.302(0.012)$ & $-0.681(0.012)$ & $-0.607(0.016)$ & $-0.109(0.021)$ & $-0.191(0.009)$ \\
\hline Workplace size $<20$ & $-1.338(0.014)$ & $-0.340(0.019)$ & $-1.219(0.022)$ & $0.887(0.032)$ & $-0.031(0.013)$ \\
\hline Workplace size 20-99 & $-0.815(0.013)$ & $-0.282(0.019)$ & $-0.719(0.021)$ & $0.212(0.032)$ & $-0.173(0.014)$ \\
\hline Workplace size $100-499$ & $-0.416(0.014)$ & $-0.115(0.020)$ & $-0.257(0.022)$ & $-0.027(0.035)$ & $-0.109(0.014)$ \\
\hline Workplace size $>500$ & - & - & - & - & - \\
\hline Reducing workplace & $0.508(0.010)$ & $-0.224(0.011)$ & $0.294(0.015)$ & $-0.407(0.016)$ & $-0.234(0.008)$ \\
\hline Expanding workplace & $0.009(0.014)$ & $-0.053(0.013)$ & $0.085(0.020)$ & $0.004(0.017)$ & $0.071(0.009)$ \\
\hline Closing workplace & $0.699(0.013)$ & $-0.602(0.017)$ & $0.985(0.018)$ & $-0.597(0.021)$ & $-0.791(0.013)$ \\
\hline No change in employment & - & - & - & - & - \\
\hline
\end{tabular}


Appendix A (continued)

\begin{tabular}{llllll}
\hline & $\begin{array}{l}\text { Stay with the } \\
\text { same firm }\end{array}$ & Public sector & $\begin{array}{l}\text { No physical } \\
\text { workplace }\end{array}$ & $\begin{array}{l}\text { Self- } \\
\text { employment }\end{array}$ & Unemployment \\
\hline dGDP & $-0.052(0.002)$ & $-0.043(0.003)$ & $-0.039(0.004)$ & $-0.046(0.004)$ & $-0.163(0.002)$ \\
Occupation dummies & Yes & Yes & Yes & Yes & Yes \\
Sector dummies & Yes & Yes & Yes & Yes & Yes \\
\hline
\end{tabular}

Note: Standard errors are in parentheses. The reference category is "stay in private sector". A replacement ratio category consisting of individuals with no previous wage, e.g., young individuals, is not presented. The number of observations is 805,781 and the Pseudo R2 is 0.1202 .

1) Individuals in this category have the same employer but a different physical workplace.

${ }^{2)}$ In the calculation of the replacement ratio, we have ignored the unemployment insurance degree (i.e. full-time, part-time, or no insurance).

Multinomial logit for flows out of private sector employment

\begin{tabular}{|c|c|c|c|c|c|}
\hline & Education & PEW & Pension & $\begin{array}{l}\text { Out of the } \\
\text { labour force }\end{array}$ & $\begin{array}{l}\text { New Labour } \\
\text { Policy }\end{array}$ \\
\hline Woman $(=1)$ & $0.253(0.014)$ & $-0.094(0.022)$ & $0.246(0.025)$ & $0.653(0.012)$ & $1.833(0.028)$ \\
\hline Ages $18-30$ & - & - & - & - & - \\
\hline Ages $31-50$ & $-2.141(0.033)$ & $-13.846(617390)$ & $2.365(0.040)$ & $0.399(0.013)$ & $0.312(0.024)$ \\
\hline Ages $>51$ & $-4.492(0.229)$ & $24.461(0.051)$ & $4.557(0.040)$ & $1.404(0.016)$ & $0.032(0.050)$ \\
\hline Replacement ratio $^{1)} 70-90 \%$ & - & - & - & - & - \\
\hline Replacement ratio $50-70 \%$ & $-0.374(0.017)$ & $0.330(0.027)$ & $-1.002(0.029)$ & $-0.364(0.013)$ & $0.709(0.031)$ \\
\hline Replacement ratio $<50 \%$ & $-1.184(0.022)$ & $-0.147(0.028)$ & $-1.073(0.029)$ & $-0.511(0.014)$ & $0.616(0.033)$ \\
\hline Workplace size $<20$ & $-0.704(0.027)$ & $-0.612(0.031)$ & $-0.272(0.042)$ & $-0.223(0.021)$ & $-0.268(0.044)$ \\
\hline Workplace size $20-99$ & $-0.572(0.027)$ & $-0.617(0.030)$ & $-0.468(0.042)$ & $-0.325(0.021)$ & $-0.231(0.043)$ \\
\hline Workplace size $100-499$ & $-0.310(0.028)$ & $-0.366(0.030)$ & $-0.321(0.045)$ & $-0.200(0.022)$ & $-0.103(0.044)$ \\
\hline Workplace size $>500$ & - & - & - & - & - \\
\hline Reducing workplace & $-0.220(0.016)$ & $-1.087(0.021)$ & $-0.476(0.026)$ & $-0.314(0.013)$ & $-0.489(0.027)$ \\
\hline Expanding workplace & $0.052(0.018)$ & $0.087(0.024)$ & $-0.122(0.032)$ & $0.056(0.015)$ & $0.018(0.029)$ \\
\hline Closing workplace & $-0.431(0.026)$ & $-2.068(0.041)$ & $-0.903(0.038)$ & $-0.490(0.018)$ & $-1.232(0.052)$ \\
\hline No change in employment & - & - & - & - & - \\
\hline .dGDP & $-0.077(0.004)$ & $-0.076(0.005)$ & $-0.036(0.006)$ & $-0.081(0.003)$ & $0.138(0.007)$ \\
\hline Occupation dummies & Yes & Yes & Yes & Yes & Yes \\
\hline Sector dummies & Yes & Yes & Yes & Yes & Yes \\
\hline
\end{tabular}

Note: Standard errors are in parentheses. The reference category is "stay in private sector".

\section{References}

Abowd, J.M., Corbel, P., Kramarz, F., 1996. The Entry and Exit of Workers and the Growth of Employment: An analysis of French Workplaces. NBER Working Paper, vol. 5551. The National Bureau of Economic Research, Cambridge (MA), USA.

Albæk, K., Sørensen, B.E., 1998. Worker and Job Flows in Danish Manufacturing, 1980-1991. The Economic Journal 108, 1750-1771.

Andersen, T.M., Dalum, B.D., Linderoth, H., Smith, V., Westergaard-Nielsen, N., 2001. The Danish Economy - An International Perspective, Copenhagen.

Anderson, P.M., Meyer, B.D., 1994. The Extent and Consequences of Job Turnover. Brookings Papers on Economic Activity. Microeconomics 177-248.

Atkinson, A., Micklewright, J., 1991. Unemployment Compensation and Labor Market Transitions: A Critical Review. Journal of Economic Literature 29 (4), 1679-1727.

Blanchard, O.J., Diamond, P., 1990. The Cyclical Behavior of the Gross Flows of U.S. Workers. Brookings Papers on Economic Activity 85-155.

Davis, S.J., Haltiwanger, J., Schuh, S., 1996. Job Creation and Destruction. MIT Press, Cambridge.

Gibbons, R., Katz, L., 1991. Layoffs and Lemons. Journal of Labour Economics 9 (4), 351-380. 
Hamermesh, D.S., Hassink, W., Van Ours, J., 1996. Job Turnover and Labor Turnover: A Taxonomy of Employment Dynamics. Annales d'Economie et de Statistique 41-42, 1-40.

Leth-Sørensen, S., 1995. The IDA database - A Longitudinal Database of Establishments and their Employees. Statistics Denmark, IDA Project.

Mortensen, Pissarides, 1999a. Job Reallocation and Employment Fluctuations. In: Woodford, M., Taylor, J.B. (Eds.), Handbook of Macroeconomics, vol. 1B. Elsevier Science, Amsterdam, pp. 1171-1227.

Mortensen, Pissarides, 1999b. New Developments in Models of Search in the Labor Market. In: Aschenfelter, O., Card, D. (Eds.), Handbook of Labor Economics, vol. 3B. Elsevier Science, Amsterdam, pp. 2567-2624.

Spence, M., 1973. Job Market Signalling. Quarterly Journal of Economics 87, 355-374.

Storrie, D.W., 1993. The Anatomy of a Large Swedish Plant Closure. Göteborgs Universitet.

Topel, R.H., Ward, M.P., 1992. Job Mobility and the Careers of Young Men. The Quarterly Journal of Economics 107 (2), 439-479.

Westergaard-Nielsen, N., 2001. 20 Years of Labour Market Policies in Denmark. In: Ilmakunnas, S. (Ed.), Labor Institutions and Employment. Government Institute for Economic Research, Helsinki. 